\title{
ПСИХОЛОГІЧНІ ОСОБЛИВОСТІ ПРОФІЛЮ САМОСТАВЛЕННЯ ОСОБИСТОСТІ В ЗАЛЕЖНОСТІ ВІД РІВНЯ ПРОЯВУ ПОЧУТТЯ СОРОМУ
}

\section{Больман Світлана Юрї̈на}

Аспірант кафедри загальної психології, Київський наиіональний університет імені Тараса Шевченка, м. Київ (Украӥна)

\begin{abstract}
Анотація. Стаття присвячена розгляду взаємозв'язку почуття сорому та самоставленням особистості. Почуття сорому розглядається у руслі емоційної сфери, як одна з моральний емоцій. Автором визначається, щуо високий рівень почуття сорому здатний призвести до формування хронічного сорому у особистості. Самоставлення у статті розглядається як трикомпонентна структура у складі Я-конщепції, яка грає регулюючу функцію. В ході опису отриманих даних досліджено корелячійні зв'язки циих двох структур, визначено особливості профілю самоставлення особистостей із умовно нормальним рівнем сорому та з хронічним соромом. Встановлено які саме компоненти самоставлення значущо різняться для обох груп, тим самим визначаючи структуру самоставлення особистості 3 хронічним соромом.
\end{abstract}

Ключові слова: почуття сорому, хронічний сором, самоставлення особистості, профіль самоставлення, регуляторна функиія.

Постановка проблеми. Почуття сорому є частиною соціального буття людини. Формування у суб'єкта здатності переживати сором обумовлено його включеністю в соціальну взаємодію та визначається зовнішніми i внутрішніми чинниками. Але будь-яке почуття у певних обставинах може підвищуватися за рівнем і ставати неадекватним зовнішній ситуації, тим самим руйнуючи деякі зв'язки із власним Я та зовнішньою реальністю, призводячи до неадекватної поведінки в ситуації сорому.
Почуття сорому виступає як інтегральна характеристика відносин особистості, визначається як регулятор внутрішніх взаємин взаємин із самим собою. За такого підходу почуття сорому відносять до категорії «моральних» емоцій. У всіх своїх проявах сором зачіпає центральну ідентичність людини, а отже, стосується і самоставлення особистості. Тому взаємозв'язок почуття сорому та самоставлення $\epsilon$ актуальною і важливою проблемою, яка потребує грунтовного вивчення.

Аналіз останніх досліджень і публіка- 
цій. У сучасній психологічній науці загальноприйнятою $\epsilon$ теза про те, що категорія «ставлення» $є$ найбільш змістовною для визначення конкретної особистості. Психологи, які плідно займалися питанням ставлення особистості (Л. І. Божович, В. М. Мясищев, Д. Н. Узнадзе, В. О. Ядов та ін.) [6, 10], виходили із відомого положення Б. Г. Ананьєва про роль ставлення людини до себе як найважливішого фактору виникнення і стабілізації єдності особистості.

Психологічна природа ставлення достатньо складна і різноманітна. Одні дослідники (В. М. Мясищев, В. О. Ядов $[6,10])$ пов'язують іï 3 активністю, інші (Л .І. Божович, Ю. А. Приходько, Г. І. Щукина, Н. А. Морозова, В. С. Мухіна) - $з$ емоційною сферою, з формою психічної діяльності, найбільш представленою у мотиваційноемоційній сфері особистості (К. А. Альбуханова-Славська, О. М. Леонтьев, Е. Л. Рубинштейн $[3,7])$. Найчастіше ставлення розглядають як мотиваційно-емоційну спрямованість активності особистості (В. К. Вилюнас, С. П. Крягжде, В. М. Мясищев, Е. У. Ширяев, В. О. Ядов, С. Г. Якобсон $[6,10,11])$.

H. I. Сарджвелазде вперше ввів категорію «самоставлення» в наукову термінологію як спеціальне поняття, класифікуючи його як підклас соціальної установки [8].

У роботах, присвячених вивченню самосвідомості, використовується поняття Я- концепція, яке тісно пов'язане 3 категорією «самоставлення». Цим терміном прийнято позначати сукупність усіх уявлень індивіда про себе. При цьому описову складову Яконцепції називають образом «Я»; складову, пов'язану зі ставленням до себе або окремих своїх якостей - самооцінкою; сукупність власних самооцінок - як прийняття себе; поведінкові реакції, викликані образом «Я» та самоставленням утворюють поведінкову складову Я-концепції.

Таким чином, самосвідомість є утворенням, що складається з трьох компонентів: когнітивного, афективного, поведінкового, котрі мають відносну незалежну логіку розвитку, однак у своєму реальному функціонуванні виявляють взаємозв'язок.

За такою логікою, визначаємо, що самоставлення також має три рівні у своїй структурі - когнітивний, емоційний та поведінковий. Цю ідею підтверджують також і роботи Н. І. Сарджвеладзе, який вказує на його трикомпонентну структуру, яка має когнітивну, емоційну та конативну складові частини [8].

За результатами досліджень В. В. Століна макроструктура самоставлення складається 3: самоповаги, аутосимпатії, самоінтересу, які завдяки адитивності даної структури інтегруються в загальне почуття позитивного або негативного ставлення до себе [9]. Для цього він використовує поняття «глобальне самоставлення», яке він розглядає як суму 
емоційних компонентів [9, с. 170 - 171]. Крім того, серед похідних ознак самоставлення В. В. Столін включає ще й ставлення від інших, самовпевненість, самоприйняття, самокерівництво, самозвинувачення, саморозуміння.

Самоставлення - це структура, що має свої складові і рівні. На нашу думку, самоставлення здатне до саморегуляції, відповідно до внутрішніх чи зовнішніх змін. Серед внутрішніх факторів, що чинять значний вплив на самоставлення, його компоненти та регулюючу функцію є почуття сорому, як компонента, що має спільні дотичні компоненти. Тому розглянемо детальніше поняття почуття сорому та його особливості.

У вітчизняній психології існує декілька взаємодоповнюючих точок зору на визначення почуття сорому: його прийнято відносити до категорії етичних/моральних почуттів (Ю. I. Сидоренко, Г. Х. Шингаров, П. М. Якобсон, А. П. Растігеев)[11]; в рамках теорії морального розвитку та виховання він розглядається як регулятивні здібності, що розвиваються в якості емоційної сторони моральності (В. А. Малахов, С. Г. Якобсон, В. Г. Щур [4, 11]). Визнано, що в основі переживання почуття сорому лежить здатність до моральної самосвідомості, яка розвивається протягом соціалізації індивіда, формування його внутрішнього «Я»; $з$ точки зору культурологічних та антропологічних теорій, сором розглядається як регулятивний механізм соціального конт- ролю, що виник разом 3 появою соціальних норм, стандартів, ідеалів (Г. А. Брандт, І. С. Кон, К. Муздибаев, Т. Г. Стефаненко [2, 5]).

К. Ізард визначає сором як усвідомлення власної невмілості, непридатності або неадекватності в певній ситуації або при виконанні певного завдання, що супроводжується негативним переживанням - прикрістю, занепокоєнням або тривогою. У людини, що зазнає почуття сорому, редукуються сфери інтересів. К. Ізард звертає увагу на те, що сором супроводжується підвищеним усвідомленням «селфі». Мова йде про незвичайну форму сприйняття «селфі» - сприйняття себе безпорадним, маленьким, ні до чого нездатним, застиглим, емоційно вразливим [1].

Велика роль сорому відмічена й у саморозвитку, розвитку самоконтролю. Подолання сорому і протистояння йому допомагають людині знайти почуття особистісної ідентичності та психологічної свободи. Адекватною реакці$є ю$ на переживання сорому можна злічити готовність індивіда до самовдосконалення. Сором викликає загострену увагу індивіда до самого себе або до деяких аспектів «Я», а значить, подальше осмислення ситуації, що викликала сором, і власні переживання, сприяє розширенню знань індивіда про себе.

Саме тому, ми вважаємо, що почуття сорому є одним із способів регуляції самоставлення особистості. Метою даної статті вбачаємо визначення особливостей профілю самоставлення відповідно до рівня прояву по- 
чуття сорому у людини.

Виклад основного матеріалу. Людина iз високим рівнем почуття сорому відчуває невпевненість, не може адекватно реагувати на зовнішні виклики, діє спонтанно або із залученням захисних механізмів, що в цілому не допомагає реалізації особистісного потенціалу, а заміщує іiі безболісними діями, які можуть допомогти людини безпечно пережити ситуацію. Умовно нормальний (середній та помірний) рівень сорому в ситуації сорому $\epsilon$ адекватною реакцією і допомагає регулювати власну поведінку, дії, стратегії, які спрямовані на вирішення ситуації, а в перспективі ще й на розвиток особистості, iї самоактуалізацію. Низький рівень сорому в ситуації, де об'єктивно людина має його відчувати відповідно до зовнішніх факторів та свої власних переконань i цінностей, також, як і високий його рівень, має більше негативний, ніж позитивний вплив на самовдосконалення, саморегуляцію.

У ході дослідження почуття сорому автором було віднайдено, що деякі особистості, при частому потраплянні в ситуації сорому або занадто інтенсивному переживанні можуть відчувати сором постійно - у них формується так званий хронічний сором. Це поняття було вперше досліджено С. Паттісоном [12], серед типів сорому він розглядає онтологічний сором, здоровий сором, гострий сором та хронічний сором. Перші три типи Паттісон визначає як ситуаційні, корисні для взаємодії особистості з зовнішнім середовищем, як вну- трішній регулятор поведінки та переживань особистості. В свою чергу, хронічний сором характеризується як неблагополучний (дезадаптивний) сором, що призводить до інтеграції особистості з власним почуттям сорому та визначає усі реакції особистості (як зовнішні, так і внутрішні); хронічний сором може стати патологічним і дезадаптивним, призводячи до руйнації особистості. Тут можемо припустити, що хронічний сором має негативний вплив на самоставлення особистості, знижуючи його функцію регуляції.

Емпіричне дослідження включало вибірку із 232 респондентів віком від 17 до 65 років, яким було запропоновано відповісти на питання анкети та психодіагностичних методик: шкала сорому когнітивно-емотивного тесту Ю. М. Орлова, Н. Д. Творогової; шкала диференціальних емоцій К. Ізарда, методика дослідження самоставлення (опитувальник МДС) (В. В. Столін, С. Р. Пантелеєв) та розроблена авторська анкета стосовно характеристик (кількісних та якісних) почуття сорому.

На основі процедури кластерного аналізу було виділено дві групи респондентів: респонденти з умовно нормальним рівнем сорому та респонденти 3 високим рівнем сорому, тобто з хронічним соромом; 176 та 56 досліджуваних відповідно. Шкали, за якими було визначено рівень сорому - шкала сорому із методики дослідження емоцій К. Ізарда, загальний рівень почуття сорому за методикою Ю. М. Орлова, чотири підшкали методики Ю. 
М. Орлова (самоприниження, раціоналізація почуття сорому, прояв агресії у ситуації сорому, проекції сорому на інших, захист від почуття сорому) та питання авторської анкети, що вимірює тривалість та інтенсивність почуття сорому, частоту ситуацій сорому та фiзіологічні прояви переживання сорому.

Подальший аналіз даних було спрямовано на визначення взаємозв'язків сорому та самоставлення, а також, на представлення та опис профілю самоставлення особистості для груп респондентів із умовно нормальним рівнем сорому та хронічним соромом.

За результатами кореляційного аналізу методом ро-Спірмена для групи респондентів, що мають умовно нормальний рівень сорому (176 осіб), було встановлено найбільш сильні кореляційні зв'язки між шкалами самостав- лення та такими характеристиками сорому, як рівень відчуття сорому та частота потрапляння у ситуації сорому.

Так, рівень сорому негативно корелює iз глобальним самоставленням $(\mathrm{r}=-0.473, \mathrm{p}=$ $0)$, самоповагою $(\mathrm{r}=-0.396, \mathrm{p}=0)$, аутосимпатією $(\mathrm{r}=-0.320, \mathrm{p}=0)$, відношенням інших $(\mathrm{r}$ $=-0.309, \mathrm{p}=0)$, самовпевненістю $(\mathrm{r}=-0.459, \mathrm{p}$ $=0)$ та самоінтересом ( $\mathrm{r}=-0.337, \mathrm{p}=0)$ (рис.1). Частота сорому дещо слабкіше, але також негативно, корелює із глобальним самоставленням $(\mathrm{r}=-0.319, \mathrm{p}=0)$, самоповагою $(\mathrm{r}=-0.292, \mathrm{p}=0)$, аутосимпатією $(\mathrm{r}=-0.256, \mathrm{p}$ $=0.001)$, самовпевненістю $(\mathrm{r}=-0.266, \mathrm{p}=0)$ та самоприйняттям $(\mathrm{r}=-0.259, \mathrm{p}=0.001)$.

Такі дані свідчать, що при підвищенні рівня сорому, самоставлення особистості знижується, особливо за рахунок самовпевненос-

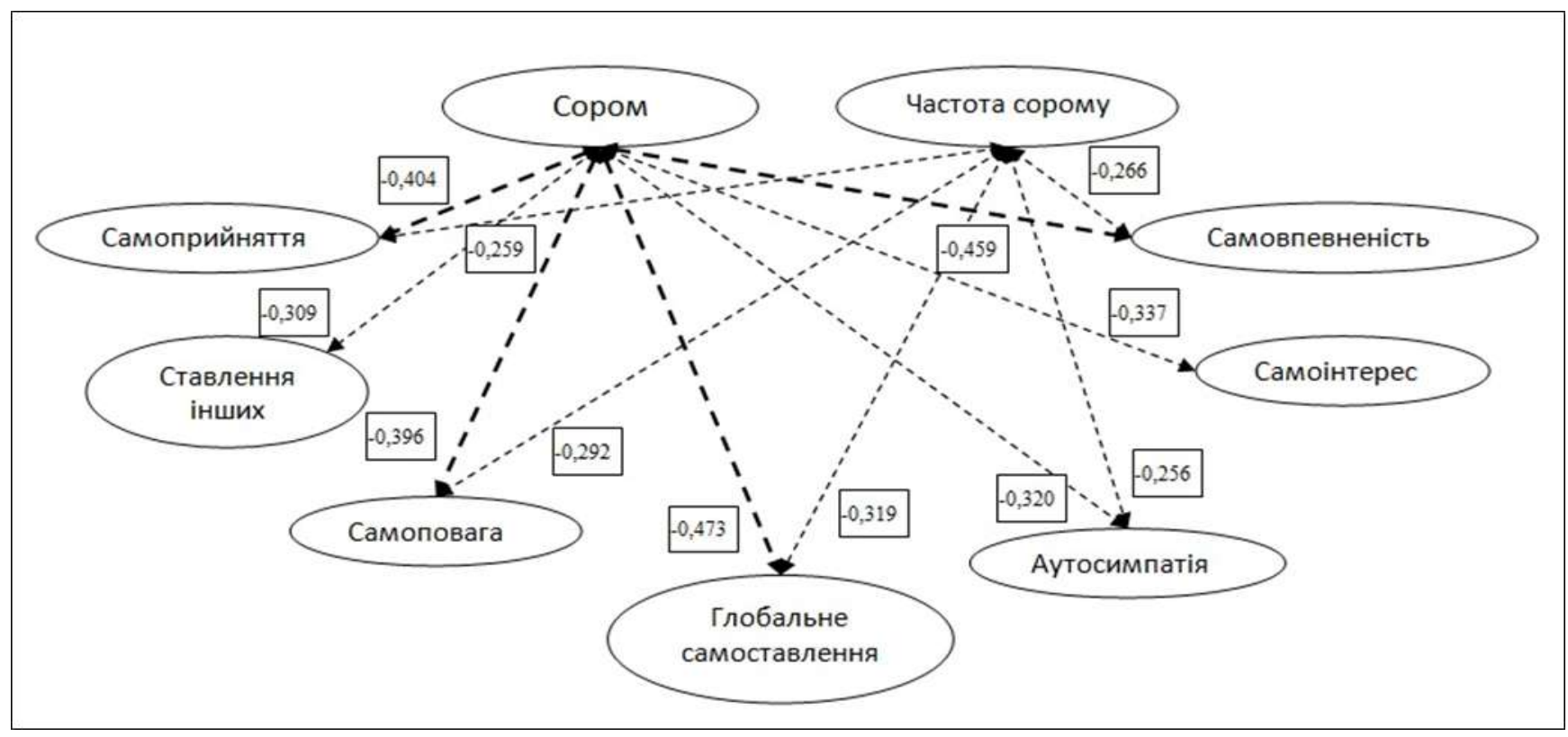

Рис. 1. Кореляційна плеяда взаємозв'язків сорому та самоставлення для групи респондентів, що мають умовно нормальний рівень сорому 
ті та само прийняття - ці компоненти знижуються в першу чергу. При цьому частота потрапляння людини в ситуації сорому та, власне, часте виникнення почуття сорому також знижує самоставлення особистості, призводячи до того, що людина перестає поважати себе i свої дії, не вірить у свої сили i, як наслідок, не відчуває симпатії до себе, глобальне «за і проти себе» зміщується у негативну сторону «проти себе».

Далі було проведено кореляційний аналіз для групи респондентів, що мають хронічний сором (56 осіб). На рис. 2 можемо бачити, що взаємозв'язок почуття сорому та самоставлення особистості у даній групі сильніший та охоплює більше змінних .

Кореляційні зв'язки стали сильніше, залишившись негативними. При цьому на перший план виступили складові сорому, основні способи переживання цього почуття, які стали основою появи хронічного сорому (проекція, агресія, раціоналізація та самоприниження).

Найбільш сильні кореляційні зв'язки отримано між шкалами рівня почуття сорому та самовпевненістю $(\mathrm{r}=-0.394, \mathrm{p}=0.003)$, ставленням інших ( $\mathrm{r}=-0.448, \mathrm{p}=0.001)$, аутосимпатією ( $\mathrm{r}=-0.417, \mathrm{p}=0.001)$, самоприйняттям $(\mathrm{r}=-0.434, \mathrm{p}=0.001)$ та глобальним самоставленням особистості $(\mathrm{r}=-0.428, \mathrm{p}=0.001)$.

Серед способів переживання сорому у осіб із хронічним сором найбільш частими $€$ прояви агресії, як до себе самого, так і до інших людей. Ця шкала негативно корелює із шкалами саморозуміння $(\mathrm{r}=-0.472, \mathrm{p}=0)$, самоповаги $(\mathrm{r}=-0.500, \mathrm{p}=0)$, самоприйняття $(\mathrm{r}$ $=-0.426, \mathrm{p}=0)$ та глобальним самоставленням $(\mathrm{r}=-0.523, \mathrm{p}=0)$ і позитивно - iз самозвинуваченням ( $\mathrm{r}=0.449, \mathrm{p}=0.001)$. Самоприниження позитивно корелює із самозвинуваченням $(\mathrm{r}=0.413, \mathrm{p}=0.002)$, проекція сорому не-

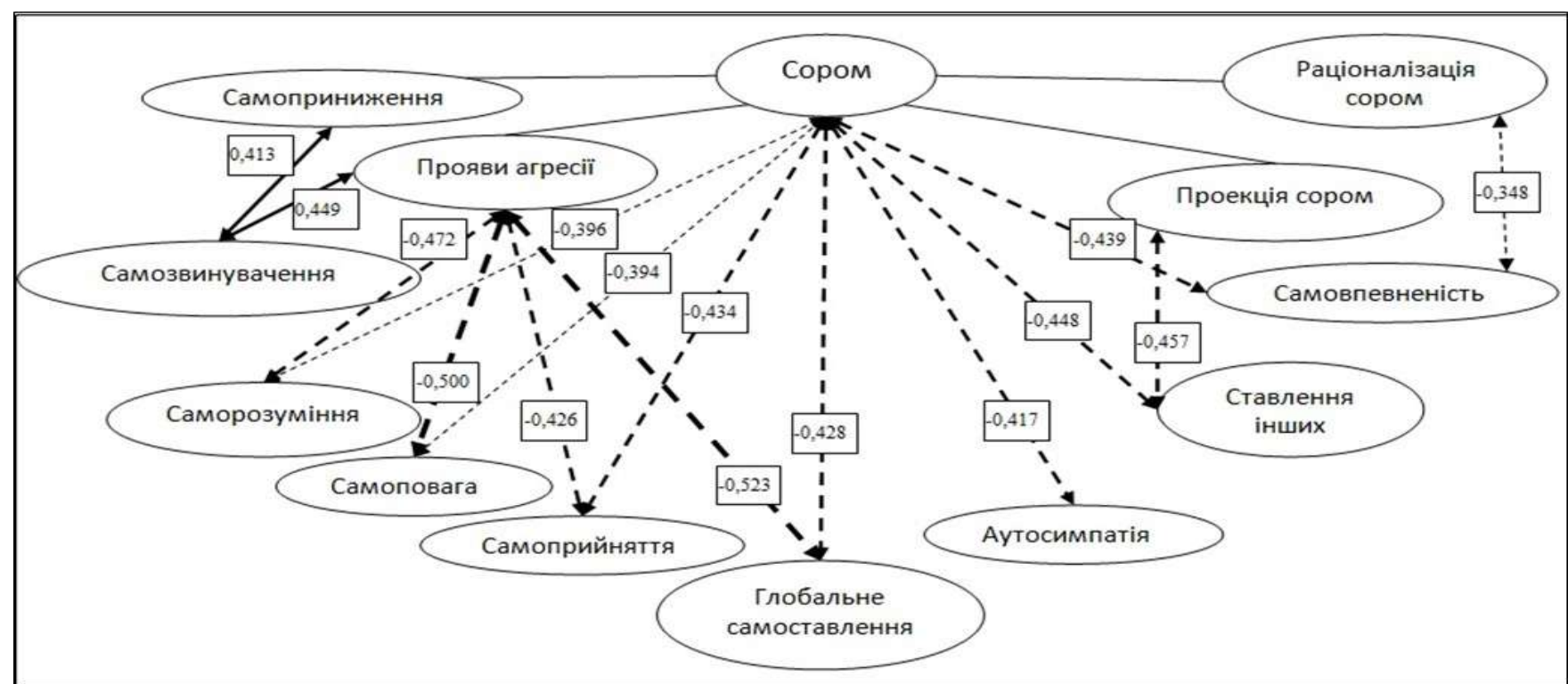

Рис. 2. Кореляційна плеяда взаємозв'язків сорому та самоставлення особистості з хронічним соромом 
гативно - із ставленням інших $(\mathrm{r}=-0.457, \mathrm{p}=$ $0)$, раціоналізація сорому негативно - із самовпевненістю $(\mathrm{r}=-0.348, \mathrm{p}=0.009)$.

3 отриманих даних ми можемо зробити висновок, що хронічний сором чинить негативний вплив на самоставлення особистості. Людина, що має хронічний сором може звинувачувати себе, принижувати інших, при цьому перекладаючи відповідальність за ситуацію чи подію, яка викликала відчуття сорому, на інших або на обставини. Почуття сорому, його інтенсивність та сила чинять болісні відчуття, що змушує людину вдаватися до захисних механізмів, інверсивних способів переживання почуття сорому, які допоможуть захистити цілісність ядра особистості, хоча будуть викривлювати профіль самоставлення особистості.

Так, для людей схильних до прояву агресії у ситуації сорому, негативні зміни самоставлення будуть найбільш помітними: суттєво знижуються такі компоненти самоставлення як повага до себе, розуміння себе і своїх дій, прийняття себе. Люди, що більше схильні проеціювати свої емоції та почуття на інших, попадають у ситуації, коли ставлення інших до них буде значно нижче, ніж раніше. Раціоналізація почуття сорому, хоч і $є$ більш здоровим захисним механізмом, але може призводити до втрати самовпевненості. А особи, що схильні до самоприниження в ситуації сорому, також мають високий рівень самозвинувачення у складі самоставлення.

Нижче представлено профіль самоставлення особистості для груп з умовно нормальним рівнем сорому та хронічним соромом. Структуру самоставлення було визначено за допомогою математичних методів.

Найбільша різниця серед основних складових самоставлення між представниками двох груп спостерігається за шкалами самоповаги та ставлення від інших (рис. 3). Глобальне самоставлення та аутосимпатія також нижчі серед представників групи з хронічним со-

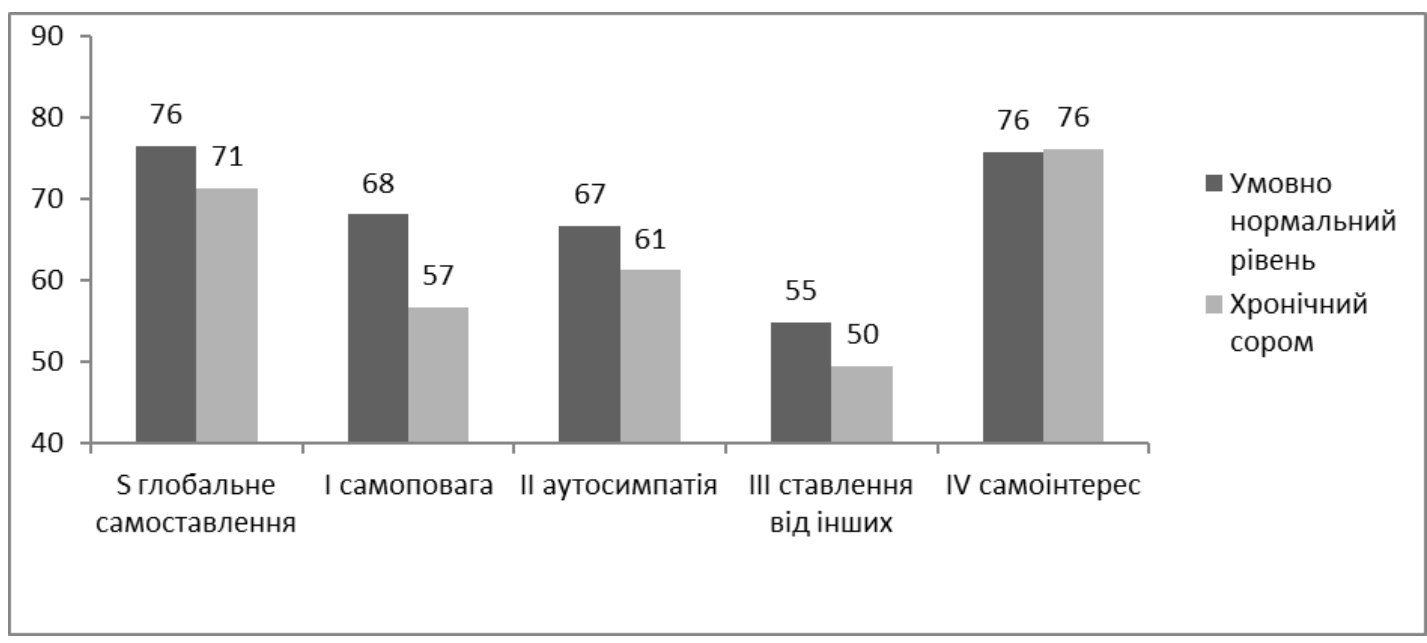

Рис. 3. Порівняння основних компонентів самоставлення для груп з умовно нормальним рівнем сорому та хронічним соромом 
ромом, при цьому шкала самоінтересу має $=0,043)$.

однаковий показних для обох груп.

Похідні шкали основних складових самоставлення для осіб із умовно нормальним рівнем сорому вищі за середнім значенням, ніж для осіб з хронічним соромом, лише рівень самозвинувачення вищий у осіб із хронічним соромом. Найбільша різниця спостерігається за шкалами самокерівництво, самоприйняття, саморозуміння. Самоінтерес, як когнітивна складова самоставлення, майже на однаковому рівні для представників обох груп (рис. 4).

При дослідженні статистично значущої різниці між результатами для двох груп за допомогою критерію U-Манна-Уітні було визначено, що групи відрізняються значимо за такими шкалами як самоповага $(\mathrm{p}=0,02)$, самокерівництво $(\mathrm{p}=0,01)$, самозвинувачення ( $\mathrm{p}$
Тобто, можемо констатувати, що хронічний сором значуще впливає на структуру самоставлення особистості, зменшуючи ії регулятивні властивості (на які вказував В. В. Столін). Проте не зважаючи на низький рівень окремих компонентів самоставлення, глобальне самоставлення значущо не знижує свого рівня за рахунок вирівнювання суми іншими компонентами структури. При підвищеному рівні сорому, аж до формування у людини хронічного сорому, самоставлення знижується, найбільше через такі компоненти як самоповага, самокерівництво та самозвинувачення.

Висновки 3 даного дослідження вказують на те, що і сором, і самоставлення особистості мають регулюючу функцію. В умовно здорової особистості ці складові особистості взаємопов'язані і цей взаємозв'язок проявля-

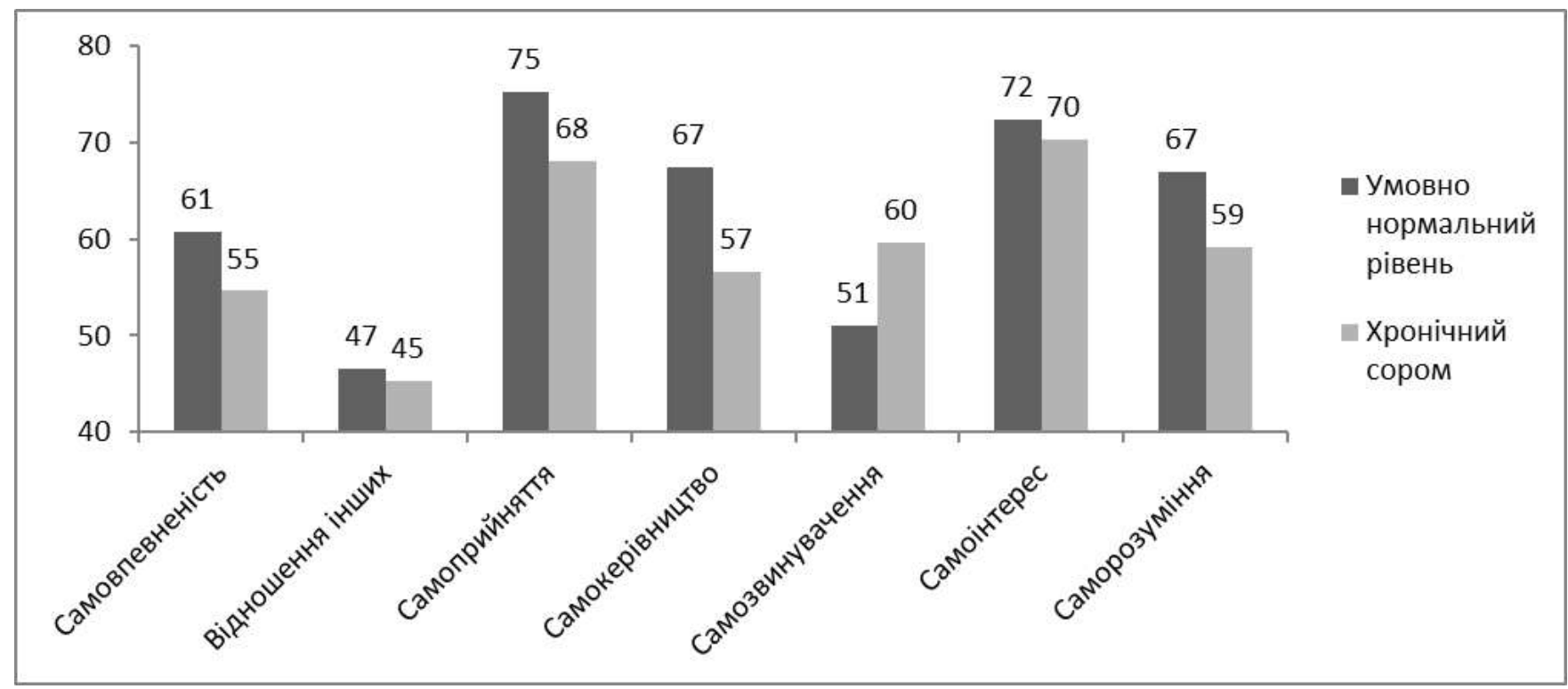

Рис. 4. Порівняння похідних компонентів самоставлення для груп з умовно нормальним рівнем сорому та хронічним соромом 
ються у тому, що рівень почуття сорому та частота потрапляння у ситуації сорому впливають на самоставлення особистості, особливо на такі їі компоненти як самовпевненість, самопочуття та самоповага.

Хронічний сором знижує регулятивні функції особистості, знижуючи загальний рівень самоставлення. Це відбувається через те, що людина з хронічним соромом схильна застосовувати захисні механізми для уникнення болісних відчуттів від занадто високого рівня сорому. Найбільш руйнівним механізмом $€$ прояв агресії в ситуації сорому - у таких особистостей підвищений рівень самозвинувачення та знижений рівень самоставлення.

Інші типи переживання почуття сорому при хронічному соромі також чинять негативний вплив на самоставлення особистості: проекція знижує доброзичливе ставлення інших, раціоналізація - самовпевненість, а самоприниження посилює самозвинувачення.

Профіль самоставлення людини із хронічним соромом відрізняється більш низькими показниками самоповаги, самокерівництва та більш високим рівнем самозвинувачення. При цьому на самоінтерес, як на когнітивний компонент самоставлення, рівень почуття сорому майже не впливає.

До перспективи подальших розвідок у даному напрямі можна віднести дослідження психологічних особливостей типів переживання сорому в осіб з хронічним соромом, їх особистісні риси, емоційні патерни, провідні за- хисні механізми. Також важливо було б дослідити особливості виховання осіб з хронічним сором, тип та стиль виховного впливу їх батьків, особливості сімейної ситуації, що можуть бути чинниками формування хронічного соромy.

\section{Перелік використаних джерел:}

1. Изард К. Э. Психология эмоций / К. Э. Изард. - СПб: Издательство «Питер», 1999. - 464 с.

2. Кон И. С. В поисках себя. Личность и ее самосознание / И. С. Кон. - М. : Изд-во политической литературы, 1984. -333 с.

3. Леонтьев В. О. Классификация эмоций / В. О. Леонтьев. - Одесса: Инновацонно-ипотечного центра, 2002. $-80 \mathrm{c}$.

4. Малахов В. А. Стыд / В. А. Малахов. - М.: Знание, 1989. $-136 \mathrm{c}$.

5. Муздыбаев К. Переживание вины и стыда / К. Мудзыбаев. - СПб. : Институт социологии РАН, 1995. - 39 c.

6. Мясищев В. Н. Психология отношений / В. Н. Мясищев; под ред. А. А. Бодалева. - М.: Московский психолого-социальный институт; Воронеж: НПО «МОДЭК», 2004. $-400 \mathrm{c}$.

7. Рубинштейн С. Л. Основы общей психологии / С. Л. Рубинштейн. - СПб. : Питер, 2007. - 713 с.

8. Сарджвеладзе Н. И. Личность и ее взаимодействие с социальной средой / Н. И. Сарджвеладзе. - Тбилиси: «Мецниереба», 1983. - 206 с.

9. Столин В. В. Самосознание личности / В. В. СтолинМ. : МГУ, 1983. $-284 \mathrm{c}$.

10. Ядов В. А. Саморегуляция и прогнозирование социального поведения личности: диспозиционная концепция / В. А. Ядов.- М. : ЦСПиМ, 2013. - 376 с.

11. Якобсон П. М. Психология чувств и мотивации / П. М. Якобсон. - Воронеж: МОДЭК; Москва: Институт практической психологии, 1998. - 304 с. 
12. Pattison S. Shame: Theory, Therapy, Theology / S. Pattison. - UK: Cambridge University Press, 2003. - 356 p.

\section{References (Transliteration):}

1. Izard K. E. Psikhologiya emotsiy / K. E. Izard. - SPb: Izdatel'stvo «Piter», 1999. - $464 \mathrm{~s}$.

2. Kon I. S. $\mathrm{V}$ poiskakh sebya. Lichnost i yeye samosoznaniye / I. S. Kon. - M.: Izd-vo politicheskoy literatury, 1984. $-333 \mathrm{~s}$.

3. Leont'yev V. A. Klassifikatsiya emotsiy / A. Leont'yev. Odessa: Innovatsonno-ipotechno tsentra, 2002. - $80 \mathrm{~s}$.

4. Malakhov V. A. Styd / V. A. Malakhov. - M .: Znaniye, 1989. - $136 \mathrm{~s}$.

5. Muzdybayev K. Perezhivaniye viny i styda / K. Mudzybayev. - SPb. : Institut sotsiologii RAN, 1995. - 39 s.

6. Myasishchev V. N. Psikhologiya otnosheniy / V. N. Myasishchev; pod red. A. A. Bodaleva. - M .: Moskovskiy psikhologo-sotsial'nyy institut; Voronezh: NPO «MODEK», 2004. - $400 \mathrm{~s}$.

7. Rubinshteyn S. L. Osnovy obshchey psikhologii / S.L. Rubinshteyn. - SPb. : Piter, 2007. - 713 s.

8. Sardzhveladze N. I. Lichnost' i yeye vzaimodeystviye s sotsial'noy sredoy / N. I. Sardzhveladze. - Tbilisi: «Metsniyereba», 1983. - $206 \mathrm{~s}$.

9. Stolin V. V. Samosoznaniye lichnosti / V. Stolin- M.: MGU, 1983. - $284 \mathrm{~s}$.

10. Yadov $V$. A. Samoregulyatsiya i prognozirovaniye sotsial'nogo povedeniya lichnosti: Dispozitsionnaya kontseptsiya / V. A. Yadov.- M.: TSSPiM, 2013. - 376 s.

11. Yakobson P.M. Psikhologiya chuvstv i motivatsii / P. M.Yakobson. - Voronezh: MODEK; Moskva: Institut prakticheskoy psikhologii, 1998. - 304 s.

12. Pattison S. Shame: Theory, Therapy, Theology / S. Pattison. - UK: Cambridge University Press, 2003. - 356 p.

\section{Bolman Svitlana}

Postgraduate student of the Department of General Psychology, Kyiv National Taras Shevchenko University, Kyiv (Ukraine)

PSYCHOLOGICAL ASPECTS OF THE SELF-ATTITUDE PROFILE OF A PERSON DEPENDING ON THE LEVEL OF MANIFESTATION OF A SENSE OF SHAME

\section{ABSTRACT}

A sense of shame is a part of the social being of a person. Formation of the ability to experience shame derives from inclusion in social interaction and is determined by external and internal factors. But any feeling in certain circumstances may increase in level and cease to be adequately relevant to the external situation, thus destroying some connections with one's own Self and external reality. A sense of shame acts as an integral characteristic of the relations of an individual and is defined as a regulator of internal relationships with oneself.

According to the research results by V. Stolin, the macrostructure of self-attitude of self-respect, autosympathy, self-interest, which, due to the additivity of this structure, are integrated into the general feeling of positive or negative attitude towards oneself. The structure of selfattitude also has three levels - cognitive, emotional and behavioural.

Self-attitude is capable of self-regulation, in accordance with internal or external changes. Among the internal factors that have significant impact on self-steering, its components and regu- 
latory function is a sense of shame as a component with common tangible components.

In the course of the research into the sense of shame, the author found that some individuals, in case of frequent or intense experience of shame can feel shame constantly - they have the socalled chronic shame. The author assumes that chronic shame has a negative effect on selfattitude of a personality, reducing its function of self-regulation.

As a result of the statistical analysis of the data obtained, it has been established that both shame and self-attitude of the person have a regulatory function. These components of a conditionally healthy personality are interrelated and this relationship is manifested in the fact that the level of feeling of shame and the frequency of experiencing the situation of shame affect the selfattitude of the individual, especially its components - self-confidence, self-sensation and selfrespect.

Chronic shame decreases the regulatory functions of the individual, reducing the overall level of self-attitude. This is due to the fact that a person with chronic shame tends to apply protective mechanisms to avoid painful feelings that originate from enormously high levels of shame.

Key words: sense of shame, chronic shame, self-attitude personality, self-attitude profile, regulatory function.

\section{Больман Светлана Юрьевна}

Аспирантка кафедры общуей психологии, Киевский национальный университет имени Тараса Шевченко, г. Киев (Украина)

\section{ПСИХОЛОГИЧЕСКИЕ ОСОБЕННОСТИ ПРОФИЛЯ САМООТНОШЕНИЯ ЛИЧНОСТИ В ЗАВИСИМОСТИ ОТ УРОВНЯ ПРОЯВЛЕНИЯ ЧУВСТВА СТЫДА}

Аннотация. Чувство стыда является частью социального бытия человека. Формирование у субъекта способности переживать стыд обусловлено его включенностью в социальное взаимодействие и определяется внешними и внутренними факторами. Но любое чувство в определенных обстоятельствах может повышаться по уровню и становиться неадекватным внешней ситуации, тем самым разрушая некоторые связи со своим Я и внешней реальностью. Чувство стыда выступает как интегральная характеристика отношений личности, определяется как регулятор внутренних взаимоотношений - взаимоотношений с самим собой.

По результатам исследований В. В. Столина макроструктура самоотношения состоит из: самоуважения, аутосимпатии, самоинтереса, которые благодаря аддитивности данной структуры интегрируются в общее чувство положительного или отрицательного отношения к себе. Самоотношение также имеет три уровня в своей структуре - когнитивный, эмоциональный и поведенческий.

Самоотношение способно к саморегуляции, в соответствии с внутренними или 
внешних изменений. Среди внутренних факторов, оказывает значительное влияние на самоотношение, его компоненты и регулирующую функцию присутствует чувство стыда, как компонент, который имеет общие касательные компоненты.

В ходе исследования чувства стыда автором было установлено, что некоторые личности при частом попадании в ситуации стыда или слишком интенсивном переживании могут испытывать стыд постоянно - у них формируется так называемый хронический стыд. Предполагаем, что хронический стыд имеет негативное влияние на самоотношение личности, снижая его функцию саморегуляции.

В результате статистического анализа полученных данных установлено, что и стыд, и самоотношение личности имеют регулирующую функцию. У условно здоровой личности эти составляющие личности взаимосвязаны и эта взаимосвязь проявляется в том, что уровень чувства стыда и частота попадания в ситуации стыда влияют на самоотношение личности, особенно на такие ее компоненты как самоуверенность, самоощущение и самоуважение.

Хронический стыд снижает регулятивные функции личности, снижая общий уровень самоотношения. Это происходит потому, что человек с хроническим стыдом склонен применять защитные механизмы для предотвращения болезненных ощущений от слишком высокого уровня стыда.
Ключевые слова: чувство стыда, хронический стыд, самоотношение личности, профиль самоотношения, регуляторная функция.
Дата отримання статті: 22.10.2017

Дата рекомендації до друку: 26.10.2017 